\title{
APPLICATION OF INTEGRATED LEARNING STRATEGY OF PROFIT NETWORK IN INCREASING LEARNING OUTCOMES OF AL QUR'AN HADIS (CASE STUDY OF CLASS XI MAN IC GOWA)
}

\author{
Hasmirawati ${ }^{1}$ \\ Muhammad Yaumi ${ }^{2}$ \\ La Ode Ismail Ahmad ${ }^{3}$ \\ Postgraduate Program of Alauddin State Islamic University Makassar, Indonesia ${ }^{1}$ \\ Alauddin State Islamic University of Makassar, Indonesia ${ }^{2,3}$ \\ hasmirawati87@gmail.com ${ }^{1}$, muhammad.yaumi@uin-alauddin.ac.id ${ }^{2}$, \\ laode.ismail@uin-alauddin.ac.id ${ }^{3}$
}

\begin{abstract}
The key issues examined are covering, how the implementation of an integrated learning strategy model Spider-webs on the subject Quran Hadis learners XI MAN IC Gowa, What the integrated learning strategy model of spider-webs can improve learning outcomes in Class X MAN IC Gowa students, and How to apply the integrated learning strategy of the Spider Web model in improving the learning outcomes of Class XI MAN IC Gowa. This research is a classroom action research conducted in the first semester of the academic year 2019-2020 consists of two cycles, each cycle consisting of 2 meetings. Furthermore, the data were analyzed qualitatively, which explains the results of actions during the teaching and learning process, and quantitatively calculated the data, namely the average score, frequency table, minimum value, maximum value, and percentage. The results showed that the integrated learning strategy of the spider-web model can improve student learning outcomes seen from an increase in the percentage of students' mastery learning, from pre-cycle to cycle I, and to cycle II, namely $29 \%$ pre- cycle there was an increase in cycle I, $82 \%$ and cycle II reached $100 \%$ and the average pre-cycle class was 67 an increase in cycle I to be 87 and in cycle II to 94 .
\end{abstract}

Keywords: Spider-Web Model; Learning Outcomes; al-Quran Hadis

\section{INTRODUCTION}

Education is an invaluable asset for individuals and society. Education is expected as an agent of reform, it should have a high responsiveness to various problems, thorough the education process it is necessary to foster awareness and responsibility of every human being, both individually and collectively to prevent the emergence of problems. ${ }^{1}$

Teaching and learning is an educational activity. Teacher expectation value is how the material presented by the teacher can be mastered by students thoroughly. This is a problem that's quite difficult for teachers to feel. This difficulty

${ }^{1}$ Darmiyati, Pendidikan Manusia (Cet. III; Jakarta: Bumi Aksara, 2010), h. 187. 
is due to students not only as individuals with all their uniqueness, but they are also social beings with different backgrounds. ${ }^{2}$

Strategy is the most important aspect in teaching and learning activities. The ability that's expected to be owned by students, will be determined by the relevance of the use of a strategy in accordance with the objectives. That means the learning objectives will be achieved by using the right strategy, in accordance with the standards of success that are embedded in a goal. ${ }^{3}$

Islam emphasizes the importance of science. Al-Qur'an and Hadis invite muslims to seek and obtain knowledge and wisdom (wisdom), and put people who are knowledgeable at a high level. Islam describes learning and learning activities by departing from the word of Allah. QS al-Nahl/16: 125.

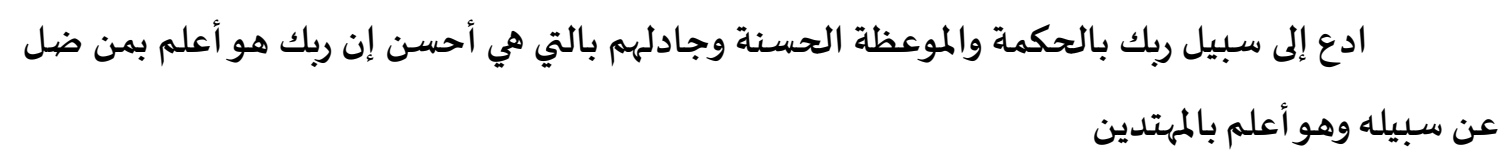

Translation:

"... Call on (the people) to the path of your Lord with good wisdom and lesson, and refute them in a good manner. Indeed, your Lord is the one who knows more about who is lost from his path and he is the one who knows better who is guided."

Education of Undang-Undang No. 20 Tahun 2003 concerning the National Education System explained that: "National Education functions to develop capabilities and shape the character and civilization of the nation, aiming at developing the potential of students to become human beings who believe in and have faith, have noble, healthy, knowledgeable knowledge, competent, creative, independently and be a democratic and responsible citizen". 5

In terms of integrate concept, skill, topic and thematic unit. The experts suggest that there are ten ways or models in planning integrated learning. The ten ways or models are: fragmented, connected, nested, sequenced, shared, spiderweb, threaded, integrated, immersed and networked. ${ }^{6}$

One of the problems facing our education world is the problem of the weak learning process. In the learning process, students are less encouraged to develop thinking skills. The learning process in the classroom is directed to the child's ability to memorize information, the child's brain is forced to remember and hoard various informations without being required to understand the information that he remembers to connect it with daily life. As a result, when our students graduate from school, they are theoretically smart, but they have poor application. ${ }^{7}$ In other words, our

${ }^{2}$ Saiful Bahri Djamarah dan Aswan Zain, Strategi Belajar Mengajar(Cet. II; Jakarta: PT Rineka Cipta: 2002), h.1.

${ }^{3}$ Abdul Majid, Strategi Pembelajaran (Cet. II; Bandung: PT Remaja Rosda Karya, 2013), h. 1.

${ }^{4}$ Departemen Agama, Al-Qur'an dan Terjemahan, (Bandung: Syamil Al-Qur'an, 2009), h. 578.

${ }^{5}$ Republik Indonesia, UU No. 20 Tahun 2003 Sistem Pendidikan Nasional (Jakarta: Menteri Pendidikan dan Kebudayaan, 2003), h. 7.

${ }^{6}$ Asep Herry Hermawan, dkk., Materi Pokok Pembelajaran Terpadu(Jakarta: Universitas Terbuka, 2007), h. 121. 2008). h. 1 .

${ }^{7}$ Wina Sanjaya, Strategi Pembelajaran (Cet. V; Jakarta: Kencana Prenadamedia Group, 


\section{Application of Integrated Learning Strategy of \\ Profit Network in Increasing Learning Outcomes of al-Qur'an Hadis \\ (Case Study of Class XI MAN IC Gowa)}

educational process is not directed towards forming creative and innovative human beings. ${ }^{8}$

Based on preliminary observations that the author has carried out on Friday, September $7^{\text {th }} 2019$, seeing that MAN IC Gowa. Students are not enthusiastic and sleepy in learning when the teacher uses the lecture method in learning, therefore the problem is focused on the average value of class XI in low Islamic Education subjects, used of appropriate methods is very influential in improving student learning outcomes. Therefore researchers interested in conducting collaborative action research, integrated learning strategies of the spider web model in an effort to improve student learning outcomes in MAN IC Gowa.

\section{DISCUSSION}

\section{The Nature of the Learning Model}

The learning model refers to the learning approach that will be used, including teaching objectives, stages in learning activities, learning environment, and classroom management. This is consistent with the opinion of Joyce that each model directs us in designing learning to help students achieve learning goals. ${ }^{9}$ Various integrated learning curriculums are developed throughout the world, but it seems that the notions of integrated learning are still many variations. ${ }^{10}$

Model of spider-web an integrated learning model that uses a thematic approach. Learning spider-web models require educators to choose the same theme. Almost the same from several competency standards in cross subjects or aspects of development. The advantage of the spider-web model, including selecting themes according to interests will motivate students, it is easier to do by inexperienced teachers, and makes it easier for students to see activities and ideas that are related.

The teacher is a professional job. In order to be able to carry out these tasks properly, in addition to fulfilling the requirements of maturity, physical and mental health, teachers must also have knowledge and teacher skills in order to be able to convey the knowledge or subjects they teach, teachers must master the science or field of study. ${ }^{11}$

The teacher should try to create conducive classroom. The class atmosphere must be democratic and not tense, but it must remain orderly so that all students can listen, speak, and express themselves optimally. ${ }^{12}$

Integrated learning spider-web model is integrated learning that uses a thematic approach. This approach development begins with determining a specific theme. Themes can be determined by negotiations between teachers and students, but can also be discussed by fellow teachers. After the theme is agreed upon, sub-themes are developed by paying attention to their links to fields of study. From sub-themes developed learning activities that student must do. ${ }^{13}$

\footnotetext{
${ }^{8}$ Wina Sanjaya, Strategi Pembelajaran, h. 2.

${ }^{9}$ Trianto, Model Pembelajaran Terpadu (Cet. IV; Jakarta: PT Bumi Aksara, 2012), h. 51.

${ }^{10}$ Trianto, Model Pembelajaran Terpadu, h. 56.

${ }^{11}$ Abdul Majid, Strategi Pembelajaran, h. 120.

${ }^{12}$ Abdul Majid, Strategi Pembelajaran, h. 135.

${ }^{13}$ Trianto, Model Pembelajaran Terpadu, h. 41.
} 
Phase of learning integrated model of spider-webs, generally in planning integrated there are several things to consider, including the profile of students who would be expected, curriculum policies, frameworks, and syllabus. To design an integrated learning spider-web model should pay attention to the following steps:

1. Determine or choose a central theme

2. Identify the concepts that will be discussed

3. Choose the appropriate learning activities

4. Develop a systematic schedule of activities. ${ }^{14}$

\section{RESEARCH METHOD}

This research is action research (classroom action research) were carried out collaboratively, which is analyzed qualitatively and quantitatively assess the improvement of student learning outcomes through the implementation of an integrated learning strategy model of spider-webs on the subjects of the Quran Hadis in MAN IC Gowa. This research is a classroom action research conducted in the first semester of the academic year 2019-2020 consists of two cycles, each cycle consisting of 2 meetings.

\section{IV.RESULT OF RESEARCH}

\section{A. Pre-Cycle}

Based on the results of test conducted by researcher preliminary observations of learning outcomes Qur'an Hadis tend to be low, and therefore researchers have designed a learning concept that use an integrated learning strategy model of spidersweb. This research is a class action research, where the implementation of the action consists of 2 cycles with 2 meetings in each cycle so that data can be obtained student learning outcomes in class XI MIA 1 at MAN IC Gowa.

The data obtained were analyzed, in quantitative form through tests conducted at the end of each cycle. Following are the learning outcomes of class XI MIA 1 students:

Table 1

List of Initial/Pre-Cycle Test Values

\begin{tabular}{cccc}
\hline No & Student's Name & Pre-Cycle Test & Information \\
\hline 1 & Respondent 1 & 70 & Not complete \\
\hline 2 & Respondent 2 & 60 & Not complete \\
\hline 3 & Respondent 3 & 60 & Not complete \\
\hline 4 & Respondent 4 & 80 & Complete \\
\hline 5 & Respondent 5 & 60 & Not complete \\
\hline 6 & Respondent 6 & 60 & Not complete \\
\hline 7 & Respondent 7 & 50 & Not complete \\
\hline 8 & Respondent 8 & 75 & Complete \\
\hline
\end{tabular}

\footnotetext{
${ }^{14}$ Shofwan Ridho, dkk., "Development of An Integrated Science Module of The Spider -Web Model on The Theme of Pests and Pesticides," Unnes Science Education Journal.http://journal.Unnes.ac.id/sju/index.php/usej (January $\left.07^{\text {th }}, 2020\right)$.
} 
Application of Integrated Learning Strategy of Profit Network in Increasing Learning Outcomes of al-Qur'an Hadis (Case Study of Class XI MAN IC Gowa)

\begin{tabular}{clcc}
\hline 9 & Respondent 9 & 65 & Not complete \\
\hline 10 & Respondent 10 & 50 & Not complete \\
\hline 11 & Respondent 11 & 70 & Not complete \\
\hline 12 & Respondent 12 & 70 & Not complete \\
\hline 13 & Respondent 13 & 70 & Not complete \\
\hline 14 & Respondent 14 & 70 & Not complete \\
\hline 15 & Respondent 15 & 80 & Complete \\
\hline 16 & Respondent 16 & 75 & Complete \\
\hline 17 & Respondent 17 & 75 & Complete \\
\hline & KKM: 72 & 1,140 & 67 \\
\hline
\end{tabular}

Table 2

Pre-Cycle Frequency and Percentage Distribution

\begin{tabular}{cccc}
\hline Value Range & Predicate & Frequency & Percentage \\
\hline $92-100$ & Very well & 0 & $0 \%$ \\
\hline $82-91$ & Well & 0 & $0 \%$ \\
\hline $72-81$ & Enough & 5 & $29 \%$ \\
\hline $0-71$ & Less & 12 & $71 \%$ \\
\hline & & 17 & $100 \%$ \\
\hline
\end{tabular}

Table 3

Description of Completeness in Pre-Cycle L earning

\begin{tabular}{cccc}
\hline Value Range & Category & Frequency & Percentage \\
\hline $0-71$ & Not complete & 12 & $71 \%$ \\
\hline $72-100$ & Complete & 5 & $29 \%$ \\
\hline & & 17 & $100 \%$ \\
\hline
\end{tabular}

Table 4

Calculations for Finding Mean (Average)

\begin{tabular}{ccc}
\hline $\mathbf{X}$ & $\mathbf{F}$ & \\
\hline 50 & 2 & 100 \\
\hline 60 & 4 & 240 \\
\hline 65 & 1 & 65 \\
\hline 70 & 5 & 350 \\
\hline 75 & 3 & 225 \\
\hline 80 & 2 & 160 \\
\hline Total & $\mathbf{N}=17$ & $\sum \mathbf{f x}=1140$
\end{tabular}

$\mathrm{Mx}=$ or $=6.7$

1. Cycle I

Table 1

Value Categorization

\begin{tabular}{ccc}
\hline No & Category & Score \\
\hline 1 & Research subject & 17 \\
\hline
\end{tabular}




\begin{tabular}{lcc}
\hline 2 & Ideal Score & 100 \\
\hline 3 & Maximum Score & 100 \\
\hline 4 & Minimum Score & 50 \\
\hline 5 & Average & 66.75 \\
\hline
\end{tabular}

Researchers give tests to the three students. The grades obtained by students are cumulative with their group mates. Meanwhile, to find out the grade average value can use the following formula:

Table 2

Calculations to find the mean (average)

\begin{tabular}{ccc}
\hline $\mathbf{X}$ & $\mathbf{f}$ & $\mathbf{F x}$ \\
\hline 60 & 2 & 120 \\
\hline 70 & 1 & 70 \\
\hline 80 & 1 & 80 \\
\hline 85 & 1 & 85 \\
\hline 90 & 6 & 540 \\
\hline 95 & 4 & 380 \\
\hline 100 & 2 & 200 \\
\hline & $\mathbf{N = 1 7}$ & \\
\hline
\end{tabular}

$$
\mathrm{Mx}=\text { or }=86.7
$$

The scores of the learning outcomes of Al-Qur'an Hadis students in the first cycle are grouped in 5 categories and obtained the frequency distribution of the scores shown in table 3 below:

Table 3

Cycle I Frequency and Percentage Table

\begin{tabular}{rcrc}
\hline Value Range & Predicate & Frequency & Percentage \\
\hline $92-100$ & Very well & 6 & $35 \%$ \\
\hline $82-91$ & Well & 7 & $41 \%$ \\
\hline $72-81$ & Enough & 1 & $6 \%$ \\
\hline-71 & Less & 3 & $18 \%$ \\
\hline & & 17 & $100 \%$
\end{tabular}

Source: Processed from Test Results

Table 3 shows that the learning outcomes of the Al-Qur'an Hadiis are quite varied and there are still students in the poor category of 3 people or $18 \%$, enough categories of 1 person or $6 \%$, either 7 people or $41 \%$ categories and categories very well 6 people or $35 \%$. The percentage of students' grades is very good in learning the Qur'an Hadis using the integrated learning strategy of the spider web model. The percentage of student attendance is very good and the learning process is dominated by all students.

If the learning outcomes of Al-Qur'an Hadis cycle I are analyzed, then the percentage of students' learning completeness in the first cycle can be seen in the following table 4 :

Table 4

Description of Completeness of Learning Cycle I Results

Value Range $\quad$ Category $\quad$ Frequency $\quad$ Percentage




\begin{tabular}{cccc}
\hline $0-71$ & Not complete & 3 & $18 \%$ \\
\hline $72-100$ & Complete & 14 & $82 \%$ \\
\hline & & 17 & $100 \%$
\end{tabular}

Source: Processed from Test Results

According to the table 4 shows that the percentage of completeness students first cycle of $82 \%$, yatitu 14 out of 17 students including complete category and $18 \%$, ie 3 out of 17 students included in the category of incomplete.

According to the table 1, 2, 3, 4 explained that the results of students of class XI MAN IC Gowa after learning through the implementation of an integrated learning strategy spider-webs models in the category of "very good" with an average score of $82,8 \%$ maximum score of 100 and minimum score of 60 . In other words $18 \%$ of class XI MIA 1 students need improvement to achieve learning goals. In this case it will be endeavored in cycle II.

\section{Cycle II}

Based on the analysis of learning outcomes graders score XI MIA 1 after application of an integrated learning strategy models Nets Spiders during the second cycle can be seen in the following table:

Table 1

Value Categorization

\begin{tabular}{ccc}
\hline No & Category & Score \\
\hline 1 & Research subject & 17 \\
\hline 2 & Ideal Score & 100 \\
\hline 3 & Maximum Score & 100 \\
\hline 4 & Minimum Score & 60 \\
\hline 5 & Average & 70 \\
\hline
\end{tabular}

From the scores of students' learning outcomes of the Qur'an Hadith listed in the above table, if grouped into the category of frequency distribution of scores, can be seen in the following table:

Table 2

Cycle Frequency Distribution and Percentage II

\begin{tabular}{cccc}
\hline Value Range & Predicate & Frequency & Percentage \\
\hline $92-100$ & Very well & 11 & $65 \%$ \\
\hline $82-91$ & Well & 5 & $30 \%$ \\
\hline $72-81$ & Enough & 1 & $5 \%$ \\
\hline-71 & Less & - & - \\
\hline & & 17 & $100 \%$ \\
\hline
\end{tabular}

Source: Processed from Test Results

If the learning outcomes Qur'an Hadis students in the second cycle are analyzed, then the percentage of student completeness learning in the second cycle can be seen in the following table 3 :

Table 3

Description of Mastery Learning Cycle II

\begin{tabular}{clll}
\hline Value Range & Category & Frequency & Percentage \\
\hline
\end{tabular}




\begin{tabular}{cccc}
\hline $0-71$ & Not complete & 0 & $0 \%$ \\
\hline $72-100$ & Complete & 17 & $100 \%$ \\
\hline & & 17 & $100 \%$ \\
\hline
\end{tabular}

\section{Source: Processed from Test Results}

Based on table 1, table 2, and table 3 it can be concluded that the learning outcomes of the Al-Qur'an Hadis students of class XI MIA 1 after being improved through the application of an integrated learning strategy of the spider web model in cycle II are in the category of "very good" with average class 94 with a maximum score of 100 and a minimum score of 80 . In calculating the average it can be obtained in the following way:

Table 4

Calculations to find the mean (average)

\begin{tabular}{ccc}
\hline $\mathbf{X}$ & $\mathbf{F}$ & $\mathbf{F x}$ \\
\hline 80 & 1 & 80 \\
\hline 86 & 2 & 172 \\
\hline 90 & 3 & 270 \\
\hline 95 & 2 & 190 \\
\hline 96 & 1 & 96 \\
\hline 97 & 1 & 97 \\
\hline 98 & 5 & 490 \\
\hline 100 & 2 & 200 \\
\hline & $\mathbf{N}=\mathbf{1 7}$ & $\sum \mathbf{F x}=\mathbf{1 . 5 9 5}$ \\
\hline
\end{tabular}

Source: Processed from Test Results

$\mathrm{Mx}=$ or $=94$

Furthermore, in table 4 will attach an increase in the quality of student learning in terms of results after the implementation of the Qur'an Hadis learning by implementing an integrated learning strategy of the spider web model in cycles I and II.

Table 5

Comparison of Pre-Cycle, Cycle I and Cycle II

\begin{tabular}{|c|c|c|c|c|c|c|c|c|c|}
\hline \multirow{2}{*}{ Cycle } & \multicolumn{3}{|c|}{$\begin{array}{c}\text { Student Achievement } \\
\text { Score }\end{array}$} & \multicolumn{2}{|c|}{ Complete } & \multicolumn{2}{|c|}{ Not complete } & \multicolumn{2}{|c|}{ Enhancement } \\
\hline & Min & $\operatorname{Max}$ & Average & F & $\%$ & $\mathrm{~F}$ & $\%$ & & \\
\hline Pre-cycle & 50 & 80 & 67 & 5 & $29 \%$ & 12 & $71 \%$ & $\mathrm{X}$ & $\%$ \\
\hline Cycle I & 60 & 100 & 86 & 14 & $82 \%$ & 3 & $18 \%$ & 19 & $53 \%$ \\
\hline Cycle II & 80 & 100 & 94 & 17 & $100 \%$ & 0 & $0 \%$ & 8 & $18 \%$ \\
\hline
\end{tabular}

Source: Processed from the results of pre-cycle, cycle I and cycle II

From the table 5 above, shows that the average score of the acquisition of students from pre-cycle to cycle I increased the maximum score from a score of 80 to a score of 100 while from cycle I to cycle II there was no increase in the maximum score remained a score of 100, and students' learning completeness of the cycle I to cycle II increase in percentage by $24 \%$.

This means that performance indicators that are understood namely an increase in learning outcomes of the Al-Qur'an Hadis in the odd semester of the 201- 


\section{Application of Integrated Learning Strategy of \\ Profit Network in Increasing Learning Outcomes of al-Qur'an Hadis}

(Case Study of Class XI MAN IC Gowa)

2020 academic year by implementing an integrated learning strategy of the spider web model has been achieved.

From the results of research conducted from September $27^{\text {th }}, 2019$ to November $29^{\text {th }}, 2019$ there was an increase from cycle I (first) to cycle II (second) ie the percentage of completeness of cycle I, namely $72 \%$ increased in cycle II to $96 \%$ with an average of 82 students, 8 in the first cycle and the average student in the second cycle is 79,2 .

Implementation of the integrated learning strategy of the spider-web model is carried out with 2 cycles and each cycle consists of $2 x$ meetings, and the end of the second meeting in each cycle held a test. The implementation of the integrated learning strategy of the spider web model in the first cycle of the learning process was carried out by implementing the integrated learning strategy of the spider web model students were immediately able to accept this model and looked very enthusiastic and interested in the spider web model. Cycle II by applying an integrated learning strategy to the spider-web model. The results of student learning activities from the cycle I and cycle II, the average class of student activities in cycle I 86.7 increased in cycle II to 94. Based on student learning outcomes from Pre-cycle to Cycle I and Cycle II, the following conclusions can be drawn: that in learning the Qur'an Hadis through the implementation of an integrated learning strategy of the spider-web model proven to be able to improve student learning outcomes in class XI MAN IC Gowa. This can be seen from the pre-cycle learning completeness $29 \%$ with an average of 67 (fair category), the first cycle of learning completeness reached $82 \%$ with an average of 86.7 included in (good category), then in the second cycle learning completeness reached $100 \%$ with an average average 94 .

\section{CONCLUSION}

Implementation of the integrated learning strategy of the spider-web model is carried out with 2 cycles and each cycle consists of $2 x$ meetings, and the end of the second meeting in each cycle held a test.

The implementation of the integrated learning strategy of the spider-web model in the first cycle of the learning process was carried out by implementing the integrated learning strategy of the spider-web model students were immediately able to accept this model and looked very enthusiastic and interested in the spider-web model. Cycle II by applying the integrated learning strategy of the spider-web model. The results of student learning activities from the cycle I and cycle II, the average class of student activities in cycle I 86.7 increased in cycle II to 94. 


\section{REFERENCE}

Dimyanti and Mudjiono. Belajar dan Pembelajaran. Cet II; Jakarta: Rineka Cipta, 2002.

Djamarah, Syaiful Bahri and Aswan Zain. Strategi Belajar Mengajar. Cet II; Jakarta: PT Rineka Cipta, 2002.

Kementerian Agama RI. Al-Quran dan Terjemahan. Bandung: Syamil Al-Quran, 2009.

Majid, Abdul. Strategi Pembelajaran. Cet.II; Bandung: PT Remaja Rosda Karya, 2003.

Republik Indonesia. Undang-Undang RI Nomor 20 Tahun 2003 tentang Sistem Pendidikan Nasional. Jakarta: Depdikbud RI, 2003.

Darajat, Zakiyah, et al. Pendidikan Islam. Cet III; Jakarta: Bumi Aksara, 2005

Hermawan, Asep Heri, et al. Materi Pokok Pembelajaran Terpadu. Jakarta: Universitas Terbuka, 2007.

Sanjaya, Wina. Strategi Pembelajaran. Ed.1, Cet.V: Jakarta Kencana, 2008.

Trianto. Model Pembelajaran Terpadu. Cet IV, Jakarta: Bumi Aksara, 2012. 